İş ve İnsan Dergisi I The Journal of Human and Work

Y1l | Year: Nisan | April 2019

Cilt-Sayı | Volume-Issue: 6 (1)

ss I pp: $13-27$

doi: 10.18394/iid.448547

e-ISSN 2148-967X

http://dergipark.gov.tr/iid/

Araştırma Makalesi

\title{
İş-Aile Çatışmasının İşten Ayrılma Niyeti Üzerindeki Etkisinde Tükenmişliğin Aracı Etkisi*
}

\author{
The Mediating Effect of Burnout on the Relationship between Work-Family Conflict \\ and Turnover Intention
}

\author{
Bora Yıldız ${ }^{\mathrm{a}}$, Muhterem Şebnem Ensarib ${ }^{\mathrm{b}}$, Meral Elçic ${ }^{\mathrm{c}}$, Melisa Erdilek Karabay
}

MAKALE BILGIISİ

Anahtar Kelimeler:

Tükenmişlik, Duygusal

Tükenme, Duyarsızlașma, Is-

Aile Catışması, İșten Ayrılma

Niyeti

Tarihler:

Geliş 27 Temmuz 2018

Düzeltme geliş 08 Aralık

2018

Kabul 13 Aralık 2018

\begin{abstract}
ÖZ
Bu araştırmada iş-aile çatışmasının işten ayrılma niyeti üzerindeki etkisinde tükenmişliğin aracı rolü Kaynakları Koruma Teorisi'ne dayandırllarak test edilmiștir. Araştırmanın amacı iş-aile çatışması ile iş̧ten ayrılma niyeti arasındaki ilişkinin tükenmişlik aractlı̆̆ ile gerçekleşip gerçekleşmediğini test etmektir. Bu bağlamda araştırma, iş-aile çatışması yaşayan çalışanları işten ayrlma niyetine iten tükenmişlik gibi olumsuz dinamiklerin etkilerini ortaya koymak açısından önem taşımaktadır. Araştırmanın örneklemini kolayda örnekleme yöntemi ile ulaşılan, kamu ve özel sektördeki hastanelerde çalışan 294 sağllk personeli oluşturmaktadır. Araştırma modeline ilișkin toplanan veri Yapısal Eșitlik Modellemesi ile test edilmiștir. Araștırma bulguları işs-aile çatışmasının tükenmişliği ve işsten ayrılma niyetini, tükenmişliğin ise iş̧ten ayrılma niyetini istatistiksel açıdan anlamlı ve pozitif yönde etkilediğini göstermiştir. Son olarak tükenmişliğin iş-aile çatışması ile işten ayrılma niyeti arasında tam aract etkiye sahip olduğu görülmektedir. Araştırma bulguları ışığında tükenmişliğin iş-aile çatışması yaşayan çalıșanların işten ayrllma niyeti geliştirmelerinde önemli bir köprü görevi gördüğü saptanmıştır.
\end{abstract}

\section{A R T ICLE INFO}

\section{Keywords:}

Burnout, Emotional

Exhaustion,

Depersonalization, Work-

Family Conflict, Turnover

Intention

Article history:

Received 27 July 2018

Received in revised form 08

December 2018

Accepted 13 December 2018

\begin{abstract}
A B S T R A C T
Building on Conservation of Resources Theory, this research examined how employees who feel work-family conflict develop turnover intention through burnout. The purpose of the study is to investigate whether the effect of work-family conflict on turnover intention appears through burnout. In this context, uncovering the effect of negative dynamics such as burnout on the direct relationship between work-family conflict and turnover intention represents the originality of the study. The sample of the study consists of 294 public and private health employees gathered by convenient sampling method. Data were analysed by using Structural Equation Modelling. Findings show that work-family conflict is statistically significant and a positive predictor of burnout and turnover intention, along with burnout is statistically significant and a positive predictor of turnover intention. Finally, burnout fully mediates the relationship between work-family conflict and turnover intention. In light of the findings, it was found that burnout plays a significant bridge role between work-family conflict and turnover intention.
\end{abstract}

\footnotetext{
* Bu çalışma 4-5 Kasım 2016 tarihinde Adana'da düzenlenmiş olan 4. Örgütsel Davranış Kongresi'nde sunulan özet bildirinin genişletilmiş tam versiyonudur.

a İletişim kurulacak yazar Doç. Dr., Istanbul Üniversitesi, İktisat Fakültesi, Işsletme bölümü, İstanbul, Türkiye. E-mail: borayildiz@istanbul.edu.tr.ORCID:0000-0002-0373-6457

${ }^{\mathrm{b}}$ Dr. Öğr. Üyesi, Okan Üniversitesi, İşletme ve Yönetim Bilimleri Fakültesi, İstanbul, Türkiye. E-mail: sebnem.ensari@okan.edu.tr. ORCID: 0000-0002-3173-2568

${ }^{\mathrm{c}}$ Doç. Dr., Gebze Teknik Üniversitesi, İșletme Fakültesi, Kocaeli, Türkiye. E-mail:emeral@gtu.edu.tr. ORCID: 0000-0002-0547-0250

d Doç. Dr., Marmara Üniversitesi, Bankacılıkve SigortacılıkYüksekokulu, Istanbul, Türkiye. E-mail: merdilek@marmara.edu.tr. ORCID: 0000-0002-7531-5790
} 


\section{GíRiş}

İnsan unsuru bir örgütteki en önemli üretim faktörlerinden biri olmakla birlikte diğer üretim faktörlerinin verimli ve etkin kullanılmasında da temel belirleyici konumundadir. Her ne kadar bu önem gerek bilimsel yazında gerekse uygulamada, çalışanlar ve örgütler tarafından bilinse de çalışan, örgüt ve yönetici kaynaklı sebeplerle göz ard1 edilebilmektedir. Bunun sonucu olarak, çalışan ile örgüt ilişkisi zedelenmekte ve çalışan işten ayrılma davranışı geliştirmektedir. Konunun önemine binaen hem bireyler ve örgütler hem de yöneticiler işten ayrılma niyetinin kendileri üzerindeki olumsuz etkilerini minimize etmek için bazı tedbirler geliştirmektedirler (Hwang \& Kou, 2006).

İş ve aile, bireylerin yaşamlarının önemli bir bölümünü oluşturduğundan, iş-aile hayatı dengesinin korunması çalışanların davranışlarında etkili önemli bir faktördür. İş-aile dengesi, bireylerin genel iyi oluş durumlarını olumlu yönde etkileyen olmazsa olmaz faktörlerden biridir (Greenhaus, Collins \& Shaw, 2003). Diğer yandan, bireylerin iş ve aile hayatlarında üstlendiği roller nedeniyle iş yaşam dengesi bozulmakta ve genellikle roller arasında çatışma yaşanabilmektedir. Bu bağlamda, iş-aile ve aile-iş çatışmalarının son yıllarda önemli bir araştırma alanı haline geldiği dikkat çekmektedir.

Yukarıdaki açıklamalara ek olarak stres kökenli tükenmişlik sendromunun işgörenler üzerindeki etkisi bilinmektedir. Tükenmişlik kavramı; çalışanların enerjilerinde azalmaya neden olan ve duygusal bir dejenerasyona sebep olan bir çeşit mesleki stres olarak tanımlandığından (Maslach, Schaufeli \& Leiter, 2001), bu stres sonucu ortaya çıkan tükenmişlik sendromu günümüzde örgütlerde önemli bir sorun olarak ortaya çıkmaktadır (Durak \& Seferoğlu, 2017). Tükenmişliğin boyutları. Şöyledir; duygusal tükenme, duyarsızlaşma ve kişisel başarı hissinde azalma (Maslach vd., 1986) Tükenmişlik sendromu bireylerin, işlerine ve örgütlerine duydukları aidiyet hissinin zayıflamasına, işyerinde karşılaşmış oldukları sıkıntılara karşı dayanma güçlerinin azalmasına ve dolayısıyla daha iyi çalışma koşullarına sahip işyerlerine geçmek için girişimde bulunmalarına neden olmaktadır (Maslach vd., 1986; Maslach, Schaufeli \& Leiter, 2001). Bu etkinin literatürde özellikle sağlık sektöründe daha çok ortaya çıktığ bazı araştırmacılar tarafından da ileri sürülmektedir (Almalki, FitzGerald \& Clark, 2012; Cheng vd., 2016; Dursun, 2012; Okan \& Özbek, 2016; Onay \& Kılc1, 2011). "Uzun süreli ve yoğun stresin bir sonucu olarak görebileceğimiz tükenmişlik sendromu, günümüz iş dünyasında, uzun süreli, yoğun ve uzaklaşılması mümkün olmayan stresin" sonuçlarından biri olarak ortaya çıkmaktadır (Şeşen, 2010). Benzer şekilde Şeşen (2010) bu durumu şöyle ifade etmektedir; "bu kaynaklar bireysel farklılıklar temelinde şekillenebildiği gibi, kişinin aile yaşantısı, sosyal ilişkileri veya iş yaşantısı temelinde de oluşabilmektedir".

Her ne kadar ilgili yazında belirtilen değişkenler arasındaki ilişkiler önceki çalışmalarca kısmi olarak ele alınmış olsa da (Tayfur \& Arslan, 2012; Onay \& Kılcı, 2011) yazında bu değişkenleri bir arada ele alan bir çalışmaya rastlanılmamıştır. Başka bir ifadeyle iş aile çatışmasının sebep olduğu işten ayrıla niyetine hangi süreçler üzerinden gidildiğini araştıran çalışmalar yetersizdir. Bu bağlamda bu çalışmada belirtilen direkt ilişkinin sanılanın aksine tükenmişlik aracılığıyla gerçekleşebileceği gerek Kaynakları Koruma Teorisi gerekse mevcut yazındaki çalışmaların dayanarak öngörülmüştür. Çalışmanın bu yönü araştırmanın özgün yanını teşkil etmektedir.

Yukarıdaki açıklamalardan hareketle bu çalışmanın amacı, yapılan önceki çalışmaları da dikkate alarak, iş-aile çatışması ile işten ayrılma niyeti arasındaki ilişkide tükenmişlik sendromunun aracı değişken etkisinin olup olmadiğı Kaynakları Koruma Teorisine dayanarak araştırmaktır. $\mathrm{Bu}$ araştırmanın sonucu olarak, ilk defa iş-aile çatışması ve işten ayrılma niyeti ilişkisinde tükenmişliğin aracı etkisi test edilerek ilgili literatürdeki bir boşluğun doldurulması hedeflenmekte ve bu şekilde çalışan davranışlarını anlama konusunda çabalayan yöneticilere katkı sağlanması amaçlanmaktadır.

\section{KURAMSAL ÇERÇEVE}

İşten ayrılma niyeti, çalışanların iş koşullarıyla alakalı memnuniyetsizlikleri dolayısıyla mevcut işlerini kendi iradeleriyle terk etme olasılığını ifade etmektedir (Kuvaas, 2006; Tett \& Meyer, 1993). Bireyin işteki sorumluluğundan dolayı ailesi ile ilgili sorumluluklarını yerine getirememesi ise "işaile çatışması" şeklinde tanımlanmaktadır (Greenhaus \& Beutell, 1985; Netemeyer vd., 1996). Diğer yandan Tükenmişlik kavramı ise kendi içerisinde üç boyut (kişisel başarı hissinde azalma, duygusal tükenme, duyarsızlaşma) barındıran mesleki bir gerilim olarak tanımlanmaktadır (Maslach vd., 2001). Bu araştırmaya konu olan değişkenler arasındaki dolaylı nedensel ilişkiler Kaynaklart Koruma Teorisi (Hobfoll, 1989) ile açıklanmaktadır. 
Kaynaklarl Koruma Teorisi (Conservation of Resources Theory) bireylerin hayatlarında çeşitli kaynaklara sahip olduğunu ve bu kaynakların insanlar için değerli olduğunu vurgulamaktadır (Hobfoll, 1989). Bu doğrultuda belirtilen kaynaklar kişilik özellikleri, çeşitli psikolojik durumlar ve enerji halleri olarak tanımlamaktadır (Hobfoll, 1989). Bu düşünceyi destekleyen başka bir bakış açısına göre pozitif psikoloji olarak adlandırılan çalışanların pozitif psikolojik kaynakları, sağlık ve mutluluk ile ilişkili olan iyi oluş durumları çalışanların önemli kaynaklarındandır (Yıldız \& Örücü, 2016). Her ne kadar pozitif psikolojik sermaye görüşü çalışanların psikolojik sağlıklarının sürdürülmesi ve korunması üzerine odaklanmış olsa da (Sheldon vd., 2000), iş ortamındaki stres kaynaklarının çalışanlar üzerindeki negatif etkileri varlığını devam ettirmektedir. Başka bir ifadeye insanın sürekli değişen bir çevrede yaşamını sürdürmesi onu diğer faktörlerin izole edildiği sadece kaynakları ile var olan bir yapı olmaktan uzaklaştırmaktadır. Teoriye göre, bu kaynaklara yönelik muhtemel ya da gerçekleşen kayıplar bireyler için en tehditkâr durumu ifade etmektedir. Başka bir söylemle, bu kayıp durumları çalışanların kaynakları üzerinde negatif etkilere sebep olan önemli stres faktörleridir. İnsanların psikolojik ve enerjik olarak iyi olma durumları pozitif bir durum olarak düşünüldügünde, iş-aile çatışması yaşayan çalışanların tükenmişlik sendromu yaşamaları neticesinde bu kaynakların zarar görmesi söz konusu olmaktadır. Dolayısıyla da kaynaklarının zarar gördüğünü fark eden çalışanların bir tür baş etme stratejisi olarak işten ayrılma niyeti geliştirebilecekleri öngörülmektedir.

\section{1. İşten Ayrılma Niyeti}

İşten ayrılma niyeti, çalışanların işin şartlarıyla ilgili hoşnutsuzluklarından ötürü hâlihazırdaki işlerini kendi arzularıyla bırakma olasılığı anlamına gelmektedir (Tett \& Meyer, 1993; Kuvaas, 2006). Çalışanın işini bırakmasının örgüt açısından ciddi sonuçlar doğurması nedeniyle işten ayrılma niyetini açıklayabilecek faktörlerin tahmin edilmesi konusu, günümüzde araştırmacılar ve uygulayıcılar tarafindan oldukça rağbet gören bir araştırma konusudur.

İsteğe bağlı işten ayrılma, işgücü performansını ve örgüt-temelli insan sermayesi birikimlerini olumsuz etkilemektedir. Bu bağlamda yetenek yönetimin gittikçe önem kazandığı günümüz iş dünyasında yetişmiş iş gücünün işten kalma niyetlerini arttıracak faaliyet ve süreçlerin etkili ve verimli bir şekilde sağlanması önem arz etmektedir. (Poyraz \& Kama, 2008).
Sağlık sektörü göz önünde bulundurulduğunda, personel devrinin hasta bakımını etkileyebileceği ve örgütler için çok maliyetli olabileceği öngörülmektedir. Dolayısıyla yüksek bir devir hızı, bir kurumun hasta ihtiyaçlarını karşılama ve kaliteli bakım sağlama kapasitesini olumsuz etkileyebilir. Ancak, işgücü devir oranını önlemek için, hastane idarelerinde işten ayrılma niyetini olumlu yönde etkileyecek ve işten ayrılma davranışlarını önleyici uygulamalara ihtiyaç vardır (Tsai vd, 2017).

\section{2. İş- Aile Çatışması}

İş ve aile yaşamın iki önemli alanıdır. Hem iş hem de ailenin taleplerini yönetmek büyük bir mücadeledir ve bu alanlar arasındaki çatışma araştırmacılar arasında önemli bir çalışma konusudur (Priyadharshini \& Wesley, 2014). Bu durum, iş ve aile alanlarındaki roller açısından farklı beklentilerin, bu alanların birinde veya her ikisinde azalmış katılım, memnuniyet ve performans ile sonuçlanabilecek çatışmalar oluşturabileceği anlamına gelmektedir (O'Driscoll vd., 2004).

İş ve aile rolleri bir bireyin hayatında muhtemelen en önemli roller arasındadır ve her bir rol, etkin bir şekilde yönetilemiyorsa çatışma çıkması kaçınılmazdır (Adisa vd., 2016). Parasuraman ve Simmers (2001) gerek aileden işe gerekse işten aileye olan yükümlülüklerin taşması durumunu eşzamanlı ortaya çıkan ve kişiyi psikolojik anlamda yoran bir çelişki durumu olarak tanımlamaktadır. İş ve aile arasındaki çatışmalar, milyonlarca yetişkin için gündelik yaşamın bir parçası olmuştur. Bu ve buna benzer bir çok durum yazında iş- aile çatışması olarak ifade edilmektedir (Greenhaus \& Beutell, 1985).

İlgili yazın incelendiğinde iş-aile çatışmasının iki yönde olabileceği söylenebilir: Birey işteki sorumluluğundan dolayı ailesi ile ilgili sorumluluklarını yerine getirememesi “iş-aile çatışması" şeklinde açıklanırken (Greenhaus \& Beutell, 1985; Netemeyer vd., 1996), bireyin ailesi ile ilgili sorumluluklarının işteki sorumluluklarını engellemesi ise "aile-iş çatışması" şeklinde açıklanmaktadır (Schultheiss, 2006). Yüksek derecede iş-aile çatışması ve aile-iş çatışmasının, potansiyel sonuçları birçok araştırmacı tarafından incelenmiştir. Yönetsel açıdan bakıldığında, bu konudaki en önemli bulgulardan biri, iş aile çatışması ve aile-iş çatışmasının işten ayrılma niyetleri ile pozitif yöndeki etkileşimidir (Amstad vd.,2011). Daha spesifik olarak bakılırsa, iş aile çatışması öncelikle iş tatminini etkilerken, aile-iş çatışması esas olarak evlilik doyumunu etkilemektedir (Nohe \& Sonntag, 2014). Bir başka deyişle, iş aile çatışması ağırlıklı olarak işle ilgili 
sonuçları etkilerken, aile-iş çatışması ağırlıklı olarak aile ile ilişkili sonuçları etkilemektedir. $\mathrm{Bu}$ çalışmada çalışanın işle ilgili sonuçları (iş-aile) üzerine odaklanıldığından, aile-iş çatışması araştırma kapsamı dışında tutulmuştur.

Rol teorisi, çalışanların şirketleri için gittikçe daha fazla çalışmaları durumunda (ekstra rol davranışı) eş ve aile sorumluluklarına daha az zaman ve enerji ayırdıklarını ileri sürmektedir. Dolayısıyla, çalışanlar Örgütsel vatandaşlık davranışları sergiledikçe, işverenlerinin görev çağrısının ötesine geçme yükümlülüğünden ve iyi bir eş ya da ebeveyn olma yükümlülüğünden muhtemelen çatışma yaşamaya başlayacaklardır (Bolino \& Turnley, 2005).

Araştırmalar, bu konudaki çatışmaların bireyleri olumsuz yönde etkilediğini belirtmektedir. Örneğin, aileye müdahale eden işin özellikleri ve işe müdahale eden ailelerin özellikleri, depresyon, stres, tükenmişlik, kaygı, düşük evlilik doyumu, düşük performans, düşük mesleki refah, yaşam memnuniyetsizliği, düşük örgütsel bağl1lık, iş tatminsizliği ve tükenmişlik gibi önemli sonuçlara neden olmaktadır (Priyadharshini \& Wesley, 2014). İki çatışma alanı arasındaki uyuşmazlık, devamsızlık, tükenmişlik ve performans (Peeters vd, 2005; Amstad vd., 2011) gibi önemli iş sonuçları üzerine; aile tatmini ve evlilik kalitesi gibi aile sonuçlarına (Voydanoff, 2004; Michel vd., 2009) ve duygusal ve fiziksel iyi olmama, depresyon ve madde kullanımı gibi bireysel sonuçlara yol açmaktadır (Frone vd., 1996; Lapierre \& Allen, 2006).

Sonuç olarak, iş-aile çatışmasının toplumsal bir mesele olduğu söylenebilir. Bu durum hem birey üzerinde stres, zihinsel dengesizlik, duygusal tükenme ve yaşam memnuniyetsizliği gibi sağlikla ilgili çeşitli sorunlara yol açmakta hem de örgütlerde, işe devamsızlık, görev performansında azalma, işten ayrılma niyetinde artış, verimsizlikte artış gibi sonuçlar doğurmakta bu da nihayetinde sürdürülebilir rekabet gücünde azalma meydana getirmektedir.

\subsection{Tükenmişlik}

İşletmeler önceden belirlenen amaçlara ulaşabilmek için çalışanlara en verimli şekilde çalışmalarını sağlayacak ortamı sağlamakla yükümlüdürler. Stres, çalışanların performans, verimlilik, tatmin ve işyeri davranışlarını doğrudan etkileyen bir faktördür (Onay \& Kılcı, 2011). Tükenmişlik kavramı, çalışanların genel iyi oluşlarına zarar veren bir nevi mesleki stres olarak tanımlandığından (Maslach vd., 2001), bu stres sonucu ortaya çıkan tükenmişlik sendromu günümüzde örgütlerde önemli bir sorun olarak ortaya çıkmaktadır (Durak \& Seferoğlu, 2017).

Literatürde tükenmişlik sendromu duygusal tükenmişlik, duyarsızlaşma ve kişisel başarı hissinde azalma olmak üzere üç alt boyuttan oluşmaktadır (Maslach \& Jackson, 1981; Schaufeli vd., 1993; Kılıç \& Seymen, 2011). Duygusal tükenme, "yaptığı iş nedeniyle kendisine aşırı yüklenildiğini düşünen işgörenin buna bağlı olarak da tüketilmiş olma duygusu hissetmesi" olarak tanımlanmaktadır (Maslach \& Jackson, 1981). Duyarsızlaşmada birey, hizmet sunduğu kişilere ve çevresine karşı pek çok olumsuz nitelikte tutum içerisine girmektedir (Maslach vd, 2001; Kaçmaz, 2005). Kişisel başarı hissinde azalma ise, çalışanın bir tür düşük öz yeterlilik durumu sergilemesi neticesinde kendisini birşeyleri başarma yönünde yetersiz ve başarısız olarak görmesi olarak ifade edilmektedir (Maslach \& Jackson, 1981). Mesleki becerilerinde ve işiyle ilgili karşılaştığı kişilerle olan ilişkilerinde olumsuzluklar yaşayan birey, işinde istediği kadar ilerleme kaydedemediğini ve gerilediğini düşünerek kendini suçlu hissetmektedir (Şıklar \& Tunalı, 2012).

Tükenmişlik sendromuna konu olan çalışanlar gerek kendileri gerekse çalıştıkları örgütler açısından verimliliğin azalmasına pasif katkı sağlayan kişiler olarak görülmektedir (Şıklar \& Tunal1, 2012). Tükenmişlik durumun birey üzerinde önemli bir stres faktörü olduğu düşünüldüğünde bu durumun gerek bireyin ailesi ile olan hayatını gerekse iş hayatını olumsuz yönde etkileyeceğini beklemek şaşırtıcı olmayacaktır (Arı vd., 2010).

\subsection{Değişkenler-arası İlişkiler ve Hipotez Geliştirme}

İş-aile yaşam dengesizliği günümüz iş koşullarının değişmesi neticesinde ortaya çıkmış bir durumdur (Guest, 2002). Rol stresi teorisi, iş-aile çatışmasını "aile ve iş alanlarından gelen rol baskılarının bazı açılardan karşılıklı olarak uyumsuz olduğu bir roller arası çatışma şekli" olarak tanımlamaktadır (Greenhaus \& Beutell, 1985). Bireyin hem özel hem de iş hayatında çeşitli olumsuz sonuçlara neden olabilme potansiyeli (Günay \& Demiralay, 2016) ve stres kaynağ önemli rol çatışmalarından birisi olarak gözlenmektedir (Colquitt, vd., 2010). İfade edilen bu tanım bu çalışmanın da çıkış noktasını oluşturmaktadir.

Uluslararası yazında çeşitli araştırmacıların (Lambert vd., 2010; Carlson vd., 2012; Nielsen vd., 2016) iş-aile çatışması ile tükenmişlik arasındaki ilişkiyi incelemeleri gözlenmekle birlikte, iş-aile çatışmasının tükenmişlik üzerindeki direkt etkisini 
araştıran çalışma sayısı yok denecek kadar azdır. Wang ve diğerleri (2012) Çin'deki sağlık personeli üzerine yaptığı araştırmasında, iş-aile çatışması ile tükenmişlik arasındaki ilişkiyi ve iş aile çatışması ile tükenmişlik arasındaki ilişkide psikolojik sermayenin aracı rolünü araştırmıştır. Bulgular; işaile çatışması ve tükenmişlik arasında pozitif yönlü bir lişiki olduğunu göstermiştir. $\mathrm{Bu}$ bağlamda geliştirilen birinci araştırma hipotezi şöyledir:

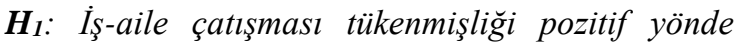 etkilemektedir.}

İşten ayrılma niyeti, fiili olarak işten ayrılmanın en güçlü öncüllerinden biridir (Griffeth, Hom \& Gaertner, 2000) ve önemli finansal maliyetlere neden olur (Allen, Bryant \& Vardaman, 2010). İşten ayrılma niyetinin artması kaza oranlarını arttırdığ1 gibi (Shaw vd., 2005) müşteri hizmetlerinin kalitesini de düşürmektedir (Hancock vd., 2013). Ayrıca, işgücü devir oranının yüksekliğinin bir işletmenin çalışanlarına yaptığg yatırımıların geri dönüşünü azaltan etmenlerden bir olduğu söylenebilir.

Stres yönetimi literatüründe kök salmış bir görüşe göre bireyler, stres faktörlerini en aza indirmeye çalıştıklarından, iş-aile çatışması doğrudan işten ayrılmaya yol açmaktadır (Greenhaus vd., 2001). İşaile çatışması yaşayan işgörenler yaşadıkları çatışmayı işlerinden ayrılarak azaltmaya çalışırlar. Böylece, işten ayrılma, birbiriyle uyumsuz iş ve aile taleplerine yanıt olarak verilmektedir. Çalışan, daha aile dostu yeni bir iş bulmak için işten ayrılmayı gerekli görür. Benzer şekilde, bir çalışanın ailevi sorumlulukları işine yansırsa, aile-iş çatışması yaşanır ve bu çatışmayı azaltmanın ve aile yükümlülüklerini daha iyi karşılamanın yolu olarak işi bırakmak düşünülebilir (Boyar vd., 2003). Bu bağlamda, kişilerin iş ve aile hayatlarında üstlendiği rollerin, talep ve ihtiyaçların aynı anda ortaya çıkması, bu ihtiyaçların ortaya çıkarttığ sorumlulukların gerektiği gibi yerine getirilmemesi bir çatışmaya neden olacak ve bu çatışma bireylerin işten ayrılma niyetleri üzerinde olumsuz bir etki yaratacaktır (Çarıkçı \& Çelikkol, 2009; Blomme, vd., 2010; Amstad, vd., 2011; Haar, vd., 2012; Masuda, vd., 2012; Nohe \& Sonntag, 2014; Karabay, 2015).

İş-aile çatışması ve işten ayrılma niyeti ilişkisi bir çok çalışma tarafindan ele alınmıştır (Anderson vd., 2002; Boyar vd., 2003; Ahuja vd., 2007; Carr vd., 2008; Wang vd., 2012; Blomme vd., 2010; Özbağ \& Çiçek, 2014). Söz konusu değişkenler arasındaki ilişkiyi inceleyen çalışmalara ulusal yazında da rastlanılmaktadır. Karabay’ın (2015) yapmış olduğu çalışmada sağlık personelinin iş stresi, iş-aile çatışması ve iş-aile hayat tatminlerine yönelik algılarının işten ayrılma niyeti üzerindeki etkisi incelenmiştir. Belirtilen çalışmada, iş-aile çatışmasının hem işten ayrılma niyeti hem de iş, aile ve hayat tatminleri üzerinde olumsuz etkisinin olduğunu ortaya koyulmuştur (Karabay, 2015). Kesitsel araştırmalar üzerine yapılan meta analizler de genel olarak iş aile çatışması ve aile-iş çatışmasının işten ayrılma niyeti ile pozitif ilişkilendirilmesini destekler niteliktedir (Allen vd., 2000; Amstad vd., 2011). Bu bilgiler 1şı̆̆ında geliştirilen ikinci araştırma hipotezi şu şekildedir:

\section{$\boldsymbol{H}_{2}$ : İs-aile çatışması işten ayrılma niyetini pozitif yönde etkilemektedir.}

İşten ayrılma niyetini etkileyen bir diğer durum olan tükenmişlik sendromunu, Ersoy, Yıldırım ve Edirne (2001) sağlık sektöründe yaptığı bir araştırmasında, bu sendromu çalışanlar arasında "yorgunluk, hayal kırıklığı ve işi bırakma" ile ortaya çıkan bir durum şeklinde tanımlamıştır. Ulusal yazında kavram, özellikle hizmet sektöründe, örgütsel bağlılık, duygusal zekâ, iş doyumu, iş stresi, rol belirsizliği ve örgütsel güven gibi konular ile ilişkilendirilmiştir (Güneş vd., 2009; Onay \& Kılc1, 2011; Çağlar, 2011). İşten ayrılma niyetini etkileyen pek çok faktör söz konusu olmakla beraber günümüzde özellikle işten ayrılma niyetinin en önemli öncüllerinden biri tükenmişlik sendromudur. Pek çok araştırmacı tükenmişlik arttıkça işten ayrılma niyetinin de arttığını çalışmalarında ortaya koymuştur (Jackson vd., 1986; Janssen vd., 1999; Houkes vd., 2001; Kim \& Stoner, 2008; Wang vd., 2012; Wong \& Laschinger, 2015; Cheng vd., 2016). Yukarıdaki açıklamalar ve ilgili literatür bağlamında geliştirilen araştırmanın üçüncü hipotezi şöyledir:

\section{$\boldsymbol{H}_{3}$ : Tükenmişlik işten ayrlma niyetini pozitif yönde etkilemektedir.}

Genel olarak ilgili yazındaki önceki araştırmalar değerlendirildiğinde, iş-aile çatışması ve işten ayrılma niyeti ilişkisini ortaya koyan birtakım çalışmalara rastlamak mümkündür. Ancak iş-aile çatışması ve işten ayrılma niyeti ilişkisinin doğasını açıklama işlevi görebilecek farklı değişkenlerin aracı etkisinin sorgulanmasına dayanan çalışmalar sinırlı düzeydedir.

Stresin olumsuz etkileri göz önüne alındığında, çalışanların deneyimledikleri stresin işten ayrılma niyetlerini etkilediği bilinmektedir (Lu vd., 2017). Konuya Kaynakları Koruma Teorisi bağlamında bakıldığında ise, çalışanların sahip olduğu pozitif durumlardan biri olan psikolojik iyi oluş yaşadıkları iş-aile çatışması sonucu zarar görmektedir. Şöyle ki, iş-aile çatışmasının sürekliliğine bağlı olarak zaman içerisinde bu pozitif enerji azalmakta hem duygusal 
hem fiziksel hem de davranışsal anlamda bir enerji kaybı -tükenme durumu- ortaya çıkmaktadır.

$\mathrm{Bu}$ çalışmadaki temel varsayım, sağlık sektöründe çalışanların iş-aile çatışmasının tükenmişliğe yol açabilecek bir stresör niteliği taşımasıdır. Yazındaki çalışmalarda sağlık sektöründe tükenmişliğin sık görülmesine sebep olabilecek hastalarla ilişkiler, hasta yakınlarıyla ilişkiler vb. gibi birçok faktörün olduğu savunmaktadır (Sünter vd., 2006: 10). Literatürde, rol çatışması bir stres faktörü olarak ifade edilmekte ve dolaylı olarak kiişiler rası çatışmaya yol açarak örgütü olumsuz etkileyebilmektedir (Soysal, 2009: 25). Başka bir ifadeyle gerek Kaynakları Koruma Teorisi gerekse geçmiş çalışmalardaki bulgulardan esinlenerek işaile çatışmasının işten ayrılma niyetini tükenmişlik vasitasıyla dolaylı olarak etkileyeceği ön görülmektedir. Buna göre geliştirilen araştırmanın dördüncü ve son hipotezi şöyledir:

H4: Tükenmişlik, iş-aile çatışması ile işten ayrılma niyeti arasındaki ilişkide aracı etkiye sahiptir.

\section{METODOLOJI}

Kolayda örnekleme yöntemi ile toplanan veri istatistiksel analiz programlarında nicel analiz yöntemleri kullanılarak analiz edilmiştir. $\mathrm{Bu}$ kapsamda araştırmada verileri analiz etmek için frekans analizi, ortalama ve standart sapma gibi tanımlayıcı istatistikler, birlikte değişim ilişkilerini test etmek için korelasyon analizi, yapı geçerliliğini test etmek için açıklayıcı ve doğrulayıcı faktör analizi, güvenilirlik düzeylerinin istenen düzeylerde olup olmadığını test etmek için güvenilirlik analizi ve son olarak nedensel ilişkileri ve aracı ilişkisinin olup olmadığını test etmek için yapısal eşitlik modellemesi (YEM) analizlerinden yararlanılmıştır.

\subsection{Araștırma Örneklemi}

Araştırmanın evrenini İstanbul ilindeki özel ve kamu sektöründeki sağlı çalışanları oluşturmaktadır. Araştırmanın örneklemini ise yine özel (142 kişi \%48,3) ve kamu (152 kişi \%51,7) kurumlarında çalışan 294 sağlık çalışanları oluşturmaktadır. Araştırmada veri toplama amaciyla anket tekniğinden yararlanılmıştır. Anket formunun ilk sayfasında araştırmanın amacı ve katılımcıların verecekleri yanıtların gizliliğine ilişkin bir bilgi formu sunulmuştur. Anket formunun ilk kısımda katılımcıların demografik bilgilerini belirlemeye yönelik ifadeler ve ikinci kısmında ise ölçeklere ilişkin Likert tarzı ifadelerden oluşan iki bölümden oluşmaktadır.

Araştırmada veri toplamak için Hair ve diğerlerinin (2010) önermiş olduğu soru sayısının 5-10 katı rakamındaki kişi sayısına ulaşılmaya çalışılmıştır. $\mathrm{Bu}$ doğrultuda 400 kişiye elden ulaştırılan anketlerin 295'i geri dönmüş (geri dönüş oran1 \%74), bu anketlerin yalnızca bir tanesi uç değer niteliği taşıdığından dolayı analiz dışı bırakılmıştır. Böylece araştırmanın örneklemini kolayda örnekleme yöntemi ile ulaşılan İstanbul ilindeki 294 sağlık çalışanı oluşturmaktadır. Araştırmaya katılan kişilerin demografik özelliklerine bakıldığında katılımcıların büyük bir çoğunluğu kadın $(\% 68,8)$, 25-30 yaş aralığında $(\% 59,3)$, medeni durumu bekar $(\% 52,2)$ lisans mezunu $(\% 61,9)$ ve 5-10 y1 aralığında (\%62) mesleki deneyime sahip sağlık çalışanlarından oluşmaktadır.

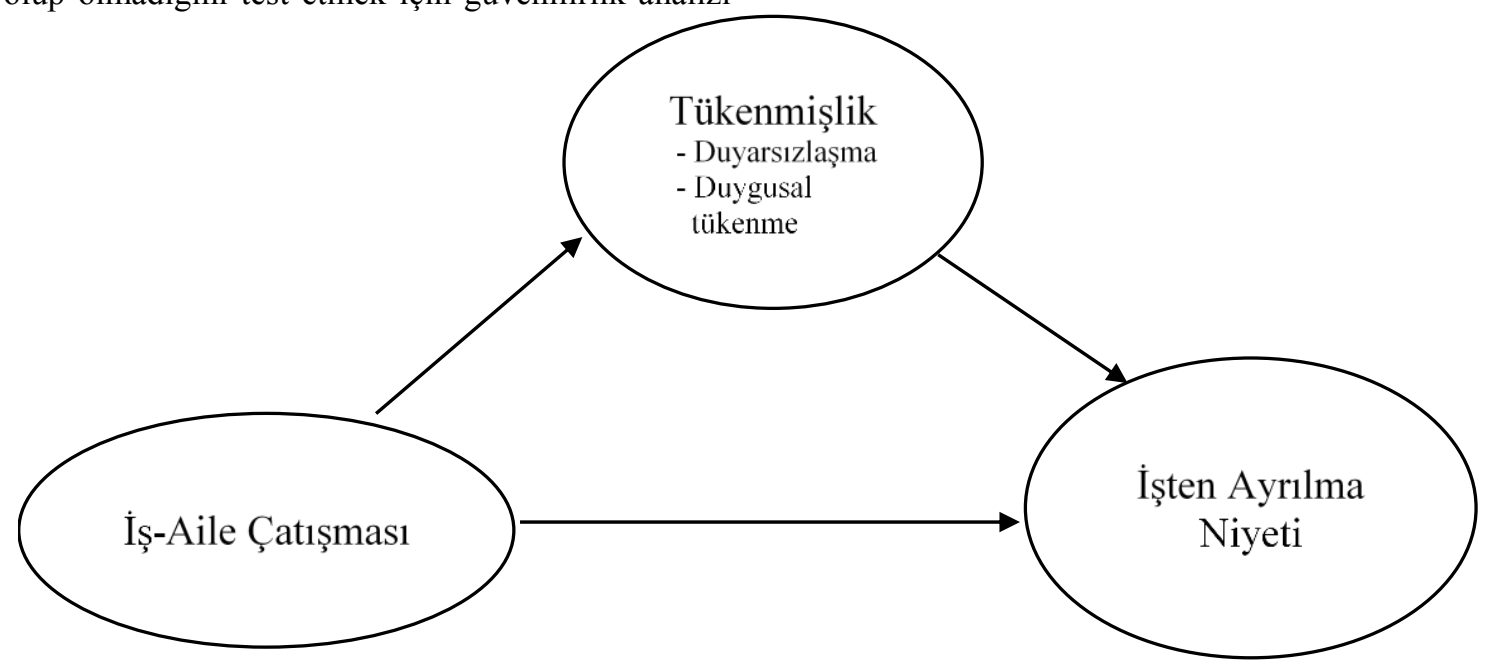

Şekil 1: Kavramsal Model 


\subsection{Araştırmada Kullanılan Ölçekler}

Gerek Türkçe çalışmalardaki ölçeklerin uygulandığı örneklemlerin farklı olması gerekse geçerlilikle ilgili faktörel dağılımlardaki tutarsız sonuçlar değerlendirildiğinde araştırmada kullanılan tüm ölçekler Brislin (1970) tarafindan önerilen geri çeviri (back translate) yöntemi kullanılarak Türkçeye uyarlanmıştır. Böylece ölçeklerin özellikle Örgütsel Davranış ve Yönetim ve Organizasyon gibi İşletme bilimi alt disiplinlerinde çalışan araştırmacı ve uygulayıcılara katkı sağlaması amaçlanmıştır.

Çalışanların tükenmişlik düzeyini belirlemek amaciyla Maslach ve Jackson (1981)'a ait yaygın olarak kullanilan (14 ifadeli: 9 ifade duygusal tükenme, 5 ifade duyarsızlaşma) Maslach Tükenmişlik Envanteri'nden (MTE) yararlanılmıştır (örnek ifade: İşimden duygusal olarak soğuduğumu hissediyorum). Orijinal kullanımda ölçek maddeleri "1 hiçbir zaman" ve "7 her zaman" biçiminde puanlanmaktadır. Ergin (1992) tarafindan Türkçe'ye çevrilen envanterde bazı değişikliklere gidilerek özgün formunda yedi dereceli olan cevap seçenekleri "0 hiçbir zaman", "5 her zaman" olarak revize edilmiştir. Bu uyarlamadan örnek alarak, bu çalışmada MTE'yi diğer değişkenlerle aynı düzeyde ölçmek için 5 dereceli hali kullanılmıştır.

İş-aile çatışma düzeyini ölçmek amacıyla Netemeyer vd. (1996) tarafından kullanılan 5 maddelik iş-aile çatışması ölçeği (örnek ifade: İsimin aldı ğ zaman aileme karşı sorumluluklarımı yerine getirmemi zorlaştırlyor), işten ayrılma niyetini ölçmek amaciyla ise Mobley vd. (1979)' nin oluşturduğu ve 3 ifadeden oluşan (örnek ifade: Yakın gelecekte işimi değiştirme niyetindeyim), likert tipi ölçeklerden yararlanılmıştır. Tüm ölçeklerdeki ifadeler, 5'li Likert ölçeği ile ölçülmüştür (1=Hiç Katılmıyorum; 5=Tamamen Katıliyorum).

\subsection{Yapı Geçerliliği}

Değişkenlere ilişkin yapı geçerliliğinin test edilmesi amaciyla öncelikle tüm faktörlerin dahil edilmiş olduğu doğal faktör çözülümünü ortaya koyan (Bektaş, 2017) açıklayıcı faktör analizi yapılmıştır. Bu bilgiler 1șığı altında tüm ölçeklere ilişkin verinin faktör analizi için yeterli olduğu tespit edilmiştir (Kaiser, 1970; Kaiser \& Rice, 1974). (Bkz. Tablo 1).

Araştırmanın bu aşamasında ölçüm (gözlenen) değişkenlerinin gizli değişkenleri ne ölçüde iyi temsil ettiklerini belirlemek için doğrulayıcı faktör analizinden yararlanılmıştır (Hair vd., 2010). Bu bağlamda belirtilen analizi gerçekleştirmek için Anderson ve Gerbing'in (1988) önermiş olduğu iki adımlı yaklaşım izlenmiştir. Buna göre modeldeki yol analizleri yapılmadan önce doğrulayıcı faktör analizi ile modelin yeterli uyum değerlerine sahip olup olmadığının belirlenmesi gerekmektedir.

Doğrulayıcı faktör analizinde modelin dataya uygun olup olmadı̆̆ını gösteren beş indeks kullanılmaktadır; $\Delta \chi^{2} / \mathrm{df}$, GFI, CFI, RMSEA ve NFI (Hair vd., 2010). Doğrulayıcı faktör analiziyle ulaşılan değerler $\left(\Delta \chi^{2} / \mathrm{df}=1,632\right.$, GFI $=0,91, \mathrm{CFI}=$ $0,97, \mathrm{NFI}=0,93, \mathrm{RMSEA}=0,046)$ alan yazında genel kabul görmüş uyum istatistik referans

Tablo 1: Açıklayıcı Faktör Analizi

\begin{tabular}{lll}
\hline Faktörler & Madde & Faktör Yük Aralığı Açılanan Varyans Cronbach Alpha \\
Sayısı &
\end{tabular}

İșten Ayrulma Niyeti

$3 \quad, 875-, 927 \quad 80,696 \quad \alpha=.88$

KM0 $=.721 ;$ Barlett $=(d f=3) 477.815 ; P<0.001$

İș Aile Çatışması

$5 \quad, 796-, 889 \quad 71,554 \quad \alpha=.90$

KM0 $=.878 ;$ Barlett $=(d f=10) 849.347 ; P<0.001$

\begin{tabular}{lcccc}
\hline Duygusal Tükenme & 9 &, $564-, 883$ & 39,242 & $\alpha=.93$ \\
\hline Duyarsızlașma & 5 &, $698-, 813$ & 26,647 & $\alpha=.87$ \\
$K M 0=.933 ;$ Barlett $=(d f=91) 2621.950 ; P<0.001$ & & \\
\hline
\end{tabular}


Tablo 2: Ölçüm Modeline İlişkin Uyuşma Geçerliliği Sonuçları

\begin{tabular}{lccc}
\hline Yapı & Soru & AVE & CR \\
\hline İşten Ayrilma Niyeti & 3 & 0,72 & 0,88 \\
Duyarsızlaşma & 5 & 0,58 & 0,87 \\
İş-Aile Çatı̧ması & 5 & 0,65 & 0,90 \\
Duygusal Tükenme & 8 & 0,64 & 0,93 \\
\hline
\end{tabular}

değerleriyle (Hair vd., 2010; Settoon vd., 1996) karşılaştırıldığında ele alınan değişkenlere ilişkin en uygun faktör yapısına ulaşıldığı görülmektedir.

Gözlenen değişkenlere ilişkin parametre tahmin değerlerinin tümü pozitif, 0,50 değerinden büyük ve istatistiksel olarak anlamlıdır. Buna göre yakınsama geçerliliği (convergent validity) sağlanmıştır (Civelek, 2018). Buna ek olarak Fornell ve Larcker (1981) tarafindan önerilen ortalama açıklanan varyans (Average Varianca Extracted (AVE)) değerleri 0,50'nin üzerinde ve her bir gizi değişkenin bileşik güvenilirlik (Composite Relability) değerleri 0,70'in üzerindedir. (Bkz. Tablo 2)

\subsection{Ayrış̧ma Geçerliliği}

Son olarak ayrışma geçerliliğini test etmek için Venkatraman'ın (1989) yaklaşımı kullanılmıştır. Bu yaklaşıma göre gizli yapıların ikili eşleştirilmesinde ortak varyansların 1'e eşitlenmesi ve serbest bırakılması durumunda bu iki test değerindeki $X^{2}$ değerleri arasındaki fark istatistiksel açıdan anlamlı olmalıdır. Başka bir söylemle bu iki değer örtüşmemelidir (Liu \& Lin, 2016). Tablo 3'den görüleceği üzere ikili modellerin $X^{2}$ değerleri kritik değerlerden farklıdır. Buna göre ölçüm modelinin ayrışma geçerliliğini sağladığı söylenebilir. (Bkz. Tablo 3)

\subsection{Ortak Metot Varyans Hatası}

Sosyal bilimlerde aynı anda birden fazla yapiya ilişkin veri toplanması (kesitsel araştırma) sürecinde ortaya çıkan ölçüm problemlerinden biri ortak metod varyans hatasıdır (Podsakoff \& Organ, 1986; Podsakoff vd., 2003). Ortak metot varyans hatasının olup olmadığı test etmeye yönelik kullanılan en yaygın yöntemlerden biri Harman'ın tek faktör metodudur (Podsakoff \& Organ, 1986). Bu yönteme göre tüm veriyi tek bir faktör analizine dâhil ettiğimizde ve herhangi bir rotasyon metodu seçmediğimizde tek ve genel bir faktör ortaya çıkıyor ise, ya da tek faktör varyansın önemli bir bölümünü tek başına açıklıyor ise ortak metot varyans hatasının varlığından söz edilebilir (Podsakoff \& Organ, 1986). Hiçbir rotasyon tekniği kullanılmadığında ve en büyük olabilirlik (maximum likelihood) metodu seçilerek verinin ham hali ile yapılan faktör analizi neticesinde ortaya çıkan faktör sayı 4 olmakla birlikte bu faktörlerin açıklamış oldukları toplam varyans miktarı $\% 63,019$ 'dur. Başka bir ifadeyle veri tek ve genel bir faktörde toplanmamaktadır. Diğer yandan faktör sayısı 1'e zorlandığında tüm gözlenen değişkenlerin tek faktörde toplandığı faktörün açıklamış olduğu toplam varyans miktarı $\% 38,261$ 'dir. Bu oran $\% 50$ varyanstan daha düşük olduğundan araştırma kapsamında toplanan veride ortak metot varyans hatasının olmadığı söylenebilir.

Tablo 3: Ayrışma geçerliliğine ilişkin istatistikler

\begin{tabular}{ccccc}
\hline Test & Açıklama & $\chi^{\mathbf{2}}$ kisitlanan model & $\chi^{\mathbf{2}}$ serbest model & Farklar $^{\mathbf{a}}$ \\
\hline & & & $\mathbf{4 8 3 . 3}$ \\
\hline 1 & TÜK $\leftarrow \rightarrow$ İAÇ & 268,511 & 212,619 & 55,892 \\
2 & TÜK $\leftarrow \rightarrow$ İAN & 178,385 & 164,389 & 13,996 \\
3 & İAÇ $\leftarrow \rightarrow$ İAN & 67,057 & 31,472 & 35,585 \\
\hline
\end{tabular}

Not: ${ }^{a}$ Tüm fark değerleri $\mathrm{p}<0,05$ anlamlılık düzeyinde istatistiksel açıdan anlamlıdır.

${ }^{b}$ TÜK: Tükenmişlik, İAÇ: İş-Aile Çatışması, İAN: İşten Ayrılma Niyeti 


\subsection{Değişkenler-arası Tanımlayıcı İstatistikler ve Korelasyon Analizi Sonuçları}

Değişkenlere ilişkin tanımlayıcı istatistikler (ortalama, standart sapma) ve güvenilirlik katsayıları ile değişkenler arası korelasyon düzeyleri Tablo 4'de sunulmuştur. (Bkz. Tablo 4)

Tablo 4'den görüldüğü üzere tüm değişkenler arasındaki ilişkiler pozitif yönde ve istatistiksel açıdan anlamlıdır $(\mathrm{p}<0,01)$. Diğer yandan parantez içerisinde gösterilen değişkenlerin güvenilirlik düzeylerine bakıldığında tüm ölçeklerin Cronbach (1951) tarafindan önerilen güvenilirlik katsayılarının $\alpha=0,70$ düzeyinden yüksek olduğu ve oldukça güvenilir oldukları söylenebilir.

\subsection{Modelin Yapısal Eşitlik Modellemesi ile Test Edilmesi}

Yol analizinde de modelin teoriyle uyumlu olduğunu ispatlamak için doğrulayıcı faktör analizi başlığı altında bahsedilen uyum indeksleri kullanılmıştır. Yol analizi ile elde edilen uyum indekslerine bakıldığında $\left(\Delta \chi^{2} / \mathrm{df}=1,502\right.$, GFI $=$ $0,92, \mathrm{CFI}=0,98, \mathrm{NFI}=0,94, \mathrm{RMSEA}=0,41)$ alan yazında genel kabul görmüş uyum istatistik referans değerleriyle (Hair vd., 2010; Settoon vd., 1996) karşılaştırıldığında test edilen modelin yeterli uyum kriterlerini sağladığg söylenebilir.

Buna göre araştırma bulguları göstermektedir ki; işaile çatışması tükenmişliği istatistiksel açıdan anlamlı ve pozitif bir şekilde etkilemektedir $(\beta=0,463 ; \quad t=4,605 ; \quad p<0,001)$. Benzer şekilde tükenmişlik işten ayrılma niyetini istatistiksel açıdan anlamlı ve pozitif bir şekilde etkilemektedir $(\beta=0,611 ; t=7,236 ; p<0,001)$. Son olarak iş-aile çatışması işten ayrılma niyetini istatistiksel açıdan anlamlı ve pozitif bir şekilde etkilemektedir $(\beta=0,302 ; \quad t=4,747 ; \quad p<0,001) . \quad B u$ bulgulardan görüldüğü üzere değişkenler arasındaki nedensel ilişkiler aracılık etkisini test etmek için yeterli koşulları sağlamaktadır. $\mathrm{Bu}$ bağlamda iş-aile çatışmasının işten ayrılma niyeti üzerindeki etkisinde tükenmişlik modele dahil edildiğinde işaile çatışması ile işten ayrılma niyeti arasındaki ilişkinin ilk modeldeki gibi hala anlamlı olmadığı $(\beta=0,014 ; \mathrm{t}=0,203 ; \mathrm{p}>0,05)$ saptanmıştır. Ayrıca ilk model ile ikinci model kıyaslandığında iş-aile çatışmasının işten ayrılma niyeti üzerindeki etkisini gösteren beta katsayısında önemli bir azalma olduğu gözlenmiştir $\left(\beta_{1}=0,302 ; \beta_{2}=0,014\right)$. Ortaya çıkan bu sonuç tükenmişliğin iş-aile çatışması ile işten ayrılma niyeti arasındaki ilişkide tam aracılık etkisine sahip olduğunu göstermektedir ve bu dolaylı etki Sobel testine (Sobel, 1982) göre istatistiksel açıdan anlamlıdır $(\mathrm{z}=5,5862 ; \mathrm{p}<0,001)$. Benzer şekilde Bootstrapt örneklem büyüklüğü 1000 olarak hesaplandığında da bu dolaylı etkinin istatistiksel açıdan anlamlı olduğu $(p<0,01)$ yukarıdaki sonuçları teyit etmektedir (Effect=0,2097; Boot SE=0,0375; BootLL99 $\mathrm{CI}=0,1177$; BootUL99 CI=0,3189). (Bkz. Tablo 5)

\section{SONUÇ, DEĞERLENDİRME ve ÖNERİLER}

Literatür incelendiğinde, iş-aile çatışmasıyla ilgili pek çok çalışmaya rastlanmakla birlikte, tükenmişlik, iş-aile çatışması ve işten ayrılma niyeti kavramları arasındaki ilişkiyi doğrudan inceleyen sınırlı sayıda çalışma yer almaktadır. Araştırma sonuçlarına göre iş-aile çatışması tükenmişliği istatistiksel açıdan anlamlı ve pozitif bir şekilde etkilemektedir. $\mathrm{Bu}$ bulgu alanyazındaki bazı araştırmaların bulguları ile tutarlılık göstermektedir (Karatepe vd., 2010; Lambert vd, 2010). Diğer taraftan, iş-aile çatışması işten ayrılma niyetinin de istatistiksel açıdan anlamlı ve pozitif bir belirleyicisi olarak bulgularda yer almaktadır. Bu da alanyazındaki pek çok araştırmanın sonucunu destekler niteliktedir (Haar, 2004; Haar vd, 2012; Mauno vd., 2015; Lu vd., 2017; Wang vd., 2017).

Tablo 4: Değişkenlere ilişkin tanımlayıcı istatistikler, korelasyon ve güvenilirlik düzeyleri

\begin{tabular}{lccccccc}
\hline Değişkenler & Ort. & Ss. & $\mathbf{1}$ & $\mathbf{2}$ & $\mathbf{3}$ & $\mathbf{4}$ & $\mathbf{5}$ \\
\hline 1. TÜK & 2,88 & 0,955 & $(0,93)$ & & & & \\
2.DUT & 3,20 & 0,987 & $0,935^{* *}$ & $(0,93)$ & & & \\
3.DUY & 2,37 & 0,549 & $0,828^{* *}$ & $0,576^{* *}$ & $(0,87)$ & & \\
4.İAÇ & 3,44 & 0,549 & $0,401^{* *}$ & $0,416^{* *}$ & $0,267^{* *}$ & $(0,90)$ & \\
5.İAN & 2,73 & 0,549 & $0,499^{* *}$ & $0,450^{* *}$ & $0,438^{* *}$ & $0,263^{* *}$ & $(0,88)$
\end{tabular}

a. TÜK: Tükenmişlik, İAÇ: İş-Aile Çatışması, İAN: İşten Ayrılma Niyeti, DUY: Duyarsızlaşma, DUT: Duygusal Tükenme **Korelasyon $\mathrm{p}<0,01$ anlamlılık düzeyinde anlamlıdır. Güvenilirlik düzeyleri (Cronbach’s Alpha) parantez içinde sunulmuştur. 
Tablo 5: Aracılık Etkisine Illişkin Yapısal Eşitlik Modeli Sonuçları

\begin{tabular}{|c|c|c|c|}
\hline Hipotezler & $\begin{array}{l}\text { Standardize Edilmiș } \\
\text { Katsayları }(\beta)\end{array}$ & $\mathbf{R}^{2}$ & $\Delta \mathbf{R}^{2}$ \\
\hline İş Aile Çatışm ası $\rightarrow$ Tükenmişlik & $0,464 * * *(\mathrm{t}=4,832)$ & 0,16 & \\
\hline Tükenmişlik $\rightarrow$ İşten Ayrılma Niyeti & $0,612 * * *(t=7,754)$ & 0,25 & \\
\hline $\begin{array}{l}\text { İş-Aile Çatışması } \rightarrow \text { İşten Ayrilma Niyeti } \\
\text { (Direkt) }\end{array}$ & $0,302 * * *(t=4,844)$ & 0,07 & 0,18 \\
\hline $\begin{array}{l}\text { İş-Aile Çatışması } \rightarrow \text { İşten Ayrilma Niyeti } \\
\text { (Dolaylı) }\end{array}$ & 0,014 ad. $(\mathrm{t}=0,203)$ & 0,25 & \\
\hline
\end{tabular}

Araştırma sonuçlarına göre, tükenmişliğin işten ayrılma niyetini anlamlı ve pozitif bir şekilde etkilemesi pek çok çalışmada elde edilen bulguları desteklemektedir (Kim \& Lee, 2009; Polat, 2009; Yürür \& Ünlü, 2011; Aslan \& Etyemez, 2015; Lu \& Gursoy, 2016). Nitekim, Telli (2012) yaptığ1 çalışmada liderlik davranış tarzları ile çalışanların tükenmişlik ve işten ayrılma eğilimleri arasında pozitif ve anlamlı bir ilişki olduğunu tespit etmiştir. Aynı ilişkiyi, Çimen (2000), sağlık çalışanları için test etmiştir.

Araştırmada, tükenmişliğin iş-aile çatışması ile işten ayrılma niyeti arasında tam aracı etkiye sahip olduğu tespit edilmiş̧tir. Bu bağlamda, yukarıda da ifade edildiği gibi bu çalışmanın ilgili yazına en temel katkısının bu aracı rolün araştırılması olduğu düşünülmektedir.

Yukarıdaki önceki araştırma bulguları ile kıyaslamalı olarak ele alınan araştırma sonuçları göstermektedir ki çalışanların bir anlamda sağlık çalışanları da oldukları düşünüldüğünde yoğun çalışma saatlerinin normal yaşamlarına da sirayet ettiği, dolayisıyla belirli bir noktadan sonra işleri ile aileleri arasında bir çatışma yaşadıkları söylenebilir. Yaşanan bu çatışma durumunun ilerleyen zaman içinde çalışanın genel stres düzeyinde bir artışa sebep olduğu ve uzun vadede bir tükenmişlik sendromumun ortaya çıkması, dolayısıyla çalışanların bu durumla baş etme taktiklerinden biri olarak işten ayrılma niyeti geliştirdikleri söylenebilir. Ortaya çıkan bu dolaylı ilişki Kaynaklarl Koruma Teorisi (Hobfoll, 1989) ile de tutarlılık göstermiştir. Başka bir ifade ile ilgili teoriden süzülerek ortaya çıkan modelin teoriyi desteklediği söylenebilir. $\mathrm{Bu}$ bulgular 1şığında kaynakları koruma teorisine dayanarak iş-aile çatışmasının bir stres kaynağı olarak tükenmişliği, tükenmişliğin ise işten ayrılma niyetini pozitif yönde etkilediği, buna ek olarak iş aile çatışmasının işten ayrılma niyetini pozitif yönde etkilediği bulguları göz önüne alındığında, bu ilişkinin tükenmişlik üzerinden gerçekleştiği saptanmıştır. $\mathrm{Bu}$ suretle iş aile çatışması yaşayan çalışanların işten ayrilma niyetlerini olumlu etkileyeceği, ancak tükenmişlik sendromuna maruz kalmaları durumunda bu etkinin daha da güçleneceği söylenebilir.

Araştırmanın uygulayıcılara sağlayacağı faydalar ise şöyle sıralanabilir: öncelikli olarak iş-aile çatışmasının işten ayrılma niyetine sebep olan bir doğaya sahip olduğu düşünüldüğünde yöneticilerin çalışanların iş-yaşam dengesini sağlayacak düzeyde optimum iş yükü vermeleri önerilmektedir. Aksi durumda çalışanların işleri tamamlayamama durumu ailelerine ayırmaları gereken zamanı azaltmalarına ve uzun vadede yaşayacakları çatışmalar sonucunda çeşitli fiziksel ve psikolojik tükenme durumlarının ortaya çıkmasına sebep olabilecektir. Bu durum ise sonrasında işten ayrılma niyeti ile sonuçlanacaktır. Diğer yandan çalışanların tükenmişlik sendromunu engelleyici çeşitli izin, terfi, ücret ve ödül gibi uygulamaların tükenmişliği azaltacağı düşünülmektedir. Benzer şekilde işlerin eşit ve insani ölçülerde paylaştırılması, çalışanların kendilerini işletmenin bir parçası olarak görmeleri ve örgütsel bağlılık yaşamaları gibi faktörlerin tükenmişliği azaltacağ 1 düşünülmektedir. $\mathrm{Bu}$ önerilere ilaveten çalışanlar ile yakından ilişki kurulması, onların şikayetlerini dinlemek, performans baskılarını minimum düzeye düşürmek ve öncelikli unsurun insan olduğu bilincinin yerleştirilmesinin işyerindeki pozitif bir iklim oluşması yönünde katk1 sağlayacağı düşünülmektedir. Son olarak, insan kaynakları yöneticilerinin iş analizi, iş tanımı ve iş gereklerini çok iyi belirleyerek kişi-iş uyumu, kişi-örgüt uyumu kavramlarının farkında olmaları ve tüm bu 
süreçlerinin üzerine en uygun kişilerin işletmeye alınmasını sağlamalarının hayati önem arz edeceği düşünülmektedir.

Sosyal bilimler alanındaki birçok araştırmada olduğu gibi bu çalışmanın da çeşitli kısıtları bulunmaktadır. Ancak bu kısıtlara firsat yaklaşımı ile bakıldığında her bir kisitın gelecek araştırmacıların ortaya koyması beklenen yeni araştırma konuları olabileceği söylenebilir. İlk olarak araştırmanın kesitsel bir araştırma olduğu düşünüldüğünde değişkenler arasında zaman temelli nedensel ilişki araştırılmamıștır. Bu bağlamda, bu çalışmanın farklı bir versiyonun boylamsal araştırmalarca ele alınması sonraki araştırmacılara önerilmektedir. Araştırmanın bir diğer kısıtı, araştırma örnekleminin sadece sağlık çalışanlarından oluşması ve örneklem büyüklüğünün 294 kişi olmasıdır. Bu çalışmanın bir benzerinin farklı sektörlerdeki ve daha büyük örneklemler üzerinde yapılması araştırma sonuçlarının genellenmesi açısından sonraki araştırmacılara önerilmektedir. Bunlara ek olarak insanın karmaşık bir yapıya sahip olduğu ve çevresel uyarıcıların sayısının tahmin düzeylerininim üzerinde olduğu düşünüldüğünde yapılan araştırmaların resmin bütününü açıklamakta yetersiz olduğu söylenebilir. Özellikle araştırmada aracı değişken olarak sadece tükenmişliğin kullanılması, başka aracı ya da şartlı değişkenlerinde modeldeki direk ilişkiyi etkileyebileceği öngörüldüğünde farklı değişkenlerin modele dahil edilmesinin ilgili yazına olan katkıyı bir adım daha ileriye taşıyacağı düşünülmektedir.

\section{KAYNAKÇA}

Adisa, T. A., Osabutey, E. L. \& Gbadamosi, G. (2016). Understanding the causes and consequences of workfamily conflict: An exploratory study of Nigerian employees. Employee Relations, 38(5), 770-788.

Ahuja, M. K., Chudoba, K. M., Kacmar, C. J., McKnight, D. H. \& George, J. F. (2007). IT road warriors: Balancing work-family conflict, job autonomy, and work overload to mitigate turnover intentions. Mis Quarterly, 1-17.

Allen, D. G., Bryant, P. C. \& Vardaman, J. M. (2010). Retaining talent: Replacing misconceptions with evidence-based strategies. The Academy of Management Perspectives, 24(2), 48-64.

Allen, T. D., Herst, D. E. L., Bruck, C. S. \& Sutton, M. (2000). Consequences associated with work-to-family conflict: A review and agenda for future research. Journal of Occupational Health Psychology, 5(2), 278-308.

Almalki, M. J., FitzGerald, G. \& Clark, M. (2012). The relationship between quality of work life and turnover intention of primary health care nurses in Saudi Arabia. BMC health services research, 12(1), 314.

Amstad, F. T., Meier, L. L., Fasel, U., Elfering, A. \& Semmer, N. K. (2011). A meta-analysis of workfamily conflict and various outcomes with a special emphasis on cross-domain versus matching-domain relations. Journal of Occupational Health Psychology, 16(2), 151-169.

Anderson, J. C. \& Gerbing, D. W. (1988). Structural equation modeling in practice: $\mathrm{A}$ review and recommended two-step approach. Psychological Bulletin, 103(3), 411.

Anderson, S. E., Coffey, B. S. \& Byerly, R. T. (2002). Formal organizational initiatives and informal workplace practices: Links to work-family conflict and job-related outcomes. Journal of management, 28(6), 787-810.

Arı, G.S., Bal, H. \& Bal, E. Ç. (2010). İșe Bağlılığın Tükenmişlik ve İşten Ayrılma Niyeti İlişkisindeki Aracılık Etkisi: Yatırım Uzmanları Üzerinde Bir Araştırma, Süleyman Demirel Üniversitesi İktisadi ve İdari Bilimler Fakültesi Dergisi, 15(3), 143-166.

Aslan, Z. \& Etyemez, S. (2015). İşgörenlerin tükenmişlik düzeylerinin işten ayrılma niyeti üzerine etkisi: Hatay'daki otel işletmelerinde bir araştırma. İşletme Araştırmaları Dergisi, 7(3), 482-507.

Bektaş, H. (2017). Açıklayıı faktör analizi. Beta Yayın Evi. 
Blomme RJ, Van Rheede A \& Tromp D. M. (2010). Work-family conflict as a cause for turnover intentions in the hospitality industry. Tourism and Hospitality Research.10, 269-85.

Bolino, M.C. \& Turnley WH, (2005). The Personal Costs of Citizenship Behavior: The Relationship Between Individual Initiative and Role Overload, Job Stress, and Work-Family Conflict, Journal of Applied Psychology, 90(4), 740-748.

Boyar, S. L., Maertz, C. P., Jr., Pearson, A. W. \& Keough, S. (2003). Work-family conflict: A model of linkages between work and family domain variables and turnover intentions. Journal of Managerial Issues, 175-190.

Brislin, R. W. (1970). Back-translation for cross-cultural research. Journal of Cross-Cultural Psychology, 1(3), 185-216.

Carlson, D., Ferguson, M., Hunter, E. \& Whitten, D. (2012). Abusive supervision and work-family conflict: The path through emotional labor and burnout. The Leadership Quarterly, 23(5), 849-859.

Carr, J. C., Boyar, S. L. \& Gregory, B. T. (2008). Themoderating effect of work-family centrality on work-family conflict, organizational attitudes, and turnover behavior. Journal of Management, 34(2), 244-262.

Cheng, C., Cheng, C., Bartram, T., Bartram, T., Karimi, L., Karimi, L. \& Leggat, S. (2016). Transformational leadership and social identity as predictors of team climate, perceived quality of care, burnout and turnover intention among nurses, Personnel Review, 45(6), 1200-1216.

Civelek, M. E. (2018). Yapısal Eşitlik Modellemesi Metodolojisi, 1. Bask1, Beta, İstanbul.

Colquitt, J., LePine, J. A., Wesson, M. J. \& Wu, X. (2010). Organizational behavior: Essentials for improving performance and commitment. New York, NY: Mcgraw-Hill Irwin.

Cronbach, L. J. (1951). Coefficient Alpha and the Internal Structure of Tests. Psychometrika, 16/3, 297-334.

Çağlar, Ç. (2011). Okullardaki Örgütsel Güven Düzeyi Ile Öğretmenlerin Mesleki Tükenmişlik Düzeyinin Bazı Değişkenler Açısından Incelenmesi, Kuram ve Uygulamada Eğitim Bilimleri, 11(4), 1827-1847.

Çarıkçı, İ. H. \& Çelikkol, Ö. (2009). İş-Aile Çatışmasının Örgütsel Bağlılık Ve İşten Ayrılma Niyetine Etkisi. Süleyman Demirel Üniversitesi Sosyal Bilimler Enstitüsü Dergisi, (9), 153-170.

Çimen, M. (2000). Türk Silahlı Kuvvetleri Sağlık Personelinin Tükenmişlik. İş Doyumu, Kuruma Bağlllık ve İşten Ayrılma Niyetlerine İlişkin Bir Alan Araştırması, Yayınlanmamış Doktora Tezi, TC
Genelkurmay Başkanlığı Gülhane Askeri Tıp Akademisi Sağlık Bilimleri Enstitüsü Sağlık Hizmetleri Yönetimi Bilim Dalı.

Durak, H. Y. \& Seferoğlu, S. S. (2017). Öğretmenlerde Tükenmişlik Duygusunun Çeşitli Değişkenler Açısından İncelenmesi. Gazi Üniversitesi Gazi Eğitim Fakültesi Dergisi, 37(2), 759-788.

Dursun, S. (2012). İşyeri şiddetinin çalışanların tükenmişlik düzeyi üzerine etkisi: Sağlık sektöründe bir uygulama. Çalışma İlişskileri Dergisi, 3(1), 105115.

Ergin, C. (1992). Doktor ve hemşirelerde tükenmişlik ve Maslach Tükenmişlik Ölçeğinin uyarlanması, VII. Ulusal Psikoloji Kongresi, Hacettepe Üniversitesi, Ankara.

Ersoy, F., Yıldırım, C. \& Edirne, T. (2001). Tükenmişlik (Staff Burnout) Sendromu. Sürekli Tip Dergisi, http://www. ttb. org. tr/sted/sted0201/1. Html erişim, 12,2014

Fornell, C. \& Larcker, D. F. (1981). Structural equation models with unobservable variables and measurement error: Algebra and statistics. Journal of Marketing Research, 18, 382-388.

Frone, M.R., Russell, M. \& Barnes, G.M. (1996). Workfamily conflict, gender, and healthrelated outcomes: a study of employed parents in two community samples, Journal of Occupational Health Psychology, 1(1), 57-69.

Greenhaus, J. H. \& Beutell, N. J. (1985). Sources of conflict between work and family roles. Academy of Management Review, 10(1), 76-88.

Greenhaus, J. H., Parasuraman, S. \& Collins, K. M. (2001). Career involvement and family involvement as moderators of relationships between work-family conflict and withdrawal from a profession. Journal of Occupational Health Psychology, 6, 91-100.

Greenhaus, J.H., Collins,K.M. \& Shaw, J.D. (2003). The relation between work-family balance and quality of life, Journal of Vocational Behavior, 63(3), 510-531.

Griffeth, R. W., Hom, P. W. \& Gaertner, S. (2000). A meta-analysis of antecedents and correlates of employee turnover: Update, moderator tests, and research implications for the next millennium. Journal of Management, 26(3), 463-488.

Guest, D. (2002). Human resource management, corporate performance and employee wellbeing: Building the worker into HRM. The journal of industrial relations, 44(3), 335-358.

Güneş, İ., Bayraktaroğlu, S. \& Kutanis, R. Ö. (2009). Çalışanların Örgütsel Bağlılık ve Tükenmişlik Düzeyleri Arasındaki Ilişki: Bir Devlet Üniversitesi 
Örneği, Süleyman Demirel Üniversitesi İktisadi ve İdari Bilimler Fakültesi Dergisi, 14(3), 481- 497.

Günay, G. Y. \& Demiralay, T. (2016). Serbest muhasebeci ve mali müşavirlerin iş stresi, tükenmişlik sendromu ve iş-aile yaşam dengesi arasındaki ilişkinin incelenmesi. Elektronik Sosyal Bilimler Dergisi, 15(58).

Haar, J. M. (2004). Work-family conflict and turnover intention: Exploring the moderation effects. New Zealand Journal of Psychology, 33(1), 35.

Haar, J. M., Roche, M. \& Taylor, D. (2012). Workfamily conflict and turnover intentions of indigenous employees: the importance of the whanau/family for Maori. The International Journal of Human Resource Management, 23(12), 2546-2560.

Hair, J. F., Black, W. C, Babin, B. J. \& Anderson, R. E. (2010). Multivariate Data Analysis: A Global Perspective ,7.Bask1, Pearson Prentice Hall, New Jersey.

Hancock, J. I., Allen, D. G., Bosco, F. A., McDaniel, K. R. \& Pierce, C. A. (2013). Meta-analytic review of employee turnover as a predictor of firm performance. Journal of Management, 39(3), 573603.

Hobfoll, S.E. (1989). Conservation of resources: A new approach at conceptualizing stress. American Psychologist, 44, 513-524.

Houkes, I., Janssen, P. P., de Jonge, J. \& Nijhuis, F. J. (2001). Specific relationships between work characteristics and intrinsic work motivation, burnout and turnover intention: A multi-sample analysis, European Journal of Work and Organizational Psychology, 10(1), 1-23.

Hwang, I.S. \& Kou, J.H. (2006). Effects of Job Satisfaction and Perceived Alternative Employment Opportunities on Turnover Intention: An Examination of Public Sector Organizations, Journal of American Academy of Business, 8(2), 254-255.

Jackson, S. E., Schwab, R. L. \& Schuler, R. S. (1986). Toward an understanding of the burnout phenomenon, Journal of Applied Psychology, 71(4), pp 630-640.

Janssen, P. P., De Jonge, J. \&Bakker, A. B. (1999). Specific determinants of intrinsic work motivation, burnout and turnover intentions: a study among nurses, Journal of Advanced Nursing, 29(6), 13601369.

Kaçmaz, N. (2005). Tükenmişlik (burnout) sendromu, İstanbul Tip Fakültesi Dergisi, 68(1), 29-32.

Kaiser, H. F. (1970). A Second Generation Little Jiffy, Psychometrika, 35/4, 401-415.
Kaiser, H. F. \& Rice, J. (1974). Little Jiffy, Mark IV, Educational and Psychological Measurement, 34/1, 111-117.

Karabay, M. (2015). Sağlı personelinin iş stresi, iş-aile çatışması ve iş-aile-hayat tatminlerine yönelik algılarının işten ayrılma niyeti üzerindeki etkilerinin belirlenmesi üzerine bir araştırma,Çanakkale 18 Mart Üniversitesi Yönetim Bilimleri Dergisi, 13(26), 113134.

Karatepe, O. M., Sokmen, A., Yavas, U. \& Babakus, E. (2010). Work-family conflict and burnout in frontline service jobs: direct, mediating and moderating effects. Economics and Management. 2010, 4, s. 61-73.

Kılıç, T. \& Seymen, O. A. (2011). Sağlık Sektöründe, Tükenmişlik Sendromuna Etki Eden Faktörlerinanalizi Ve Bir Araştırma, Yönetim ve Ekonomi Araştırmaları Dergisi, 9(16), 47-67.

Kim, H. \& Lee, S. Y. (2009). Supervisory communication, burnout, and turnover intention among social workers in health care settings. Social Work In Health Care, 48(4), 364-385.

Kim, H. \& Stoner, M. (2008). Burnout and turnover intention among social workers: Effects of role stress, job autonomy and social support, Administration In Social Work, 32(3), 5-25.

Kuvaas, B. (2006). Performance Appraisal Satisfaction and Employee Outcomes: Mediating and Moderating Roles of Work Motivation, International Journal of Human Resource Management, 17(3), 504-522.

Lambert, E., Hogan, N. L. \& Altheimer, I. (2010). The association between work-family conflict and job burnout among correctional staff: A preliminary study. American Journal of Criminal Justice, 35(1-2), 37-55.

Lapierre, L.M. \& Allen, T.D. (2006), Work-supportive family, family-supportive supervision, use of organizational benefits, and problem-focused coping: implications for work-family conflict and employee well-being, Journal of Occupational Health Psychology, 11(3), 169-181.

Liu, C. M. \& Lin, C. P. (2016). Corporate Ethical Values and Turnover Intention. Journal of Leadership \& Organizational Studies, 23(4), 397-409.

Lu, A. C. C. \& Gursoy, D. (2016). Impact of job burnout on satisfaction and turnover intention: Do generational differences matter?. Journal of Hospitality \& Tourism Research, 40(2), 210-235.

Lu, Y., Hu, X. M., Huang, X. L., Zhuang, X. D., Guo, P., Feng, L. F. \& Hao, Y. T. (2017). The relationship between job satisfaction, work stress, work-family conflict, and turnover intention among physicians in 
Guangdong, China: a cross-sectional study. BMJ open, 7(5), 1-12.

Maslach, C. \& Jackson, S. E. (1981). The measurement of experienced burnout. Journal of Organizational Behavior, 2(2), 99-113.

Maslach, C., Jackson, S. E., Leiter, M. P., Schaufeli, W. B., \& Schwab, R. L. (1986). Maslach burnout Inventory (Vol. 21, pp. 3463-3464). Palo Alto, CA: Consulting Psychologists Press.

Maslach, C., Schaufeli, W. B. \& Leiter, M. P. (2001). Job burnout. Annual review of psychology, 52(1), 397422.

Masuda, A. D., Poelmans, S. A., Allen, T. D., Spector, P. E., Lapierre, L. M., Cooper, C. L., ... \& Lu, L. (2012). Flexible work arrangements availability and their relationship with work-to-family conflict, job satisfaction, and turnover intentions: A comparison of three country clusters. Applied psychology, 61(1), 129.

Mauno, S., De Cuyper, N., Kinnunen, U., Ruokolainen, M., Rantanen, J. \& Mäkikangas, A. (2015). The prospective effects of work-family conflict and enrichment on job exhaustion and turnover intentions: comparing long-term temporary vs. permanent workers across three waves. Work \& Stress, 29(1), 75-94.

Michel, J.S., Mitchelson, J.K., Kotrba, L.M., LeBreton, J.M. \& Baltes, B.B. (2009). A comparative test of work-family conflict models and critical examination of work-family linkages, Journal of Vocational Behavior, 74(2), 199-218.

Mobley, W. H., Griffeth, R. W., Hand, H. H. \& Meglino, B. M. (1979). Review and conceptual analysis of the employee turnover process, Psychological Bulletin, 86(3), 493-522.

Netemeyer, R. G., Boles, J. S. \& McMurrian, R. (1996). Development and validation of work-family conflict and family-work conflict scales, Journal of Applied Psychology, 81(4), 400-410.

Nielsen, W., Skipstein, A. \& Demerouti, E. (2016). Adverse trajectories of mental health problems predict subsequent burnout and work-family conflicta longitudinal study of employed women with children followed over 18 years. BMC psychiatry, 16(1), 1-10.

Nohe, C., Michel, A. \& Sonntag, K. (2014). Work-family conflict, social support, and turnover intentions: A longitudinal study. Journal of Vocational Behavior, $1-12$.

O’Driscoll, M. P., Brough, P. \& Kalliath, T. J. (2004). Work/family conflict, psychological well-being, satisfaction and social support: A longitudinal study in New Zealand. Equal opportunities international, 23(1/2), 36-56

Okan, T. \& Özbek, F. (2016). İş Yükü Talebi, İş Tatminsizliği Ve İşten Ayrılma Niyeti Arasındaki İlişkilerde İş-Aile Çatışması Ve İş Stresinin Ara Değişken Rolü: Sağlı Çalışanları Örneği. Gümüşhane Üniversitesi Sosyal Bilimler Enstitüsü Dergisi, 203-226.

Onay, M. \& Kılc1, S. (2011). İş Stresi ve Tükenmişlik Duygusunun Işten Ayrılma Niyeti Üzerine Etkileri: Garsonlar ve Aşçıaşılar. Organizasyon ve Yönetim Bilimleri Dergisi, 3(2), 363-372.

Özbağ, GK. \& Çiçek, C.G. (2014). Does job satisfaction mediate the relationship between Work-family conflict and turnover? A study of Turkish marine pilots. Procedia - Social and Behavioral Sciences, 140, 43-9.

Parasuraman, S. \& Simmers, C.A. (2001). Type of Employment, Work-Family Conflict and Well-Being: A Comparative Study. Journal of Organizational Behavior. 22, 551-568.

Peeters, M., Montgomery, A., Bakker, A. \& Schaufeli, W. (2005). Balancing work and home: how job and home demands are related to burnout, International Journal of Stress Management, Vol. 12 No. 1, pp. 4361.

Podsakoff, P. M. \& Organ, D. W. (1986). Self-Reports in Organizational Research: Problems and Prospects. Journal of Management, 12/4, 531-544.

Podsakoff, P. M., MacKenzie, S. B., Lee, J.Y. \& Podsakoff, N. P. (2003). Common Method Biases in Behavioral Research: A Critical Review of The Literature and Recommended Remedies. Journal of Applied Psychology, 88/5, 879-903.

Polat, S. (2009). İlköğretim müfettişlerinin örgütsel bağlılık, mesleki tükenmişlik ve işten ayrılma niyetleri arasındaki ilişki. Education Sciences, 4(3), 1150-1159.

Poyraz, K. \& Kama, B. (2008). Algılanan iş güvencesinin, iş tatmini, örgütsel başlılık ve işten ayrılma niyeti üzerindeki etkilerinin incelenmesi. Suleyman Demirel University Journal of Faculty of Economics \& Administrative Sciences, 13(2),143165.

Priyadharshini, R.A \& Wesley, R J. (2014). Personality as a Determinant of Work-Family Conflict, Journal of Industrial Engineering and Management JIEM, 7(5): 1037-1060.

Schultheiss, D. E. P. (2006). The Interface Of Work And Family Life, Professional Psychology: Research and Practice, 37(4), 334-341. 
Schaufeli, W. B., Maslach, C. \& Marek, T. (1993). Historical and conceptual development of burnout. Professional burnout: Recent developments in theory and research, 1-16.

Settoon, R. P., Bennett, N. \& Liden, R. C. (1996). Social Exchange in Organizations: Perceived Organizational Support, Leader-Member Exchange, and Employee Reciprocity, Journal of Applied Psychology, 81/3, 219-227.

Shaw, J. D., Gupta, N., \& Delery, J. E. (2005). Alternative conceptualizations of the relationship between voluntary turnover and organizational performance. Academy of Management Journal, 48(1), 50-68.

Sheldon, K., Frederickson, B., Rathunde, K. \& Csikszentmihalyi, M. (2000). Positive Psychology Manifesto (Rev.

Ed.), http://www.positivepsychology.org/ akumalmanifesto.htm, Erişim Tarihi: 10.08.2018.

Sobel, M. E. (1982). Asymptotic confidence intervals for indirect effects in structural equation models. Sociological Methodology, 13, 290-312.

Soysal, A. (2009). İş yaşamında stres. Çimento İşveren Dergisi, 23(3), 17-40.

Sünter, A. T., Canbaz, S., Dabak, Ş., Öz, H. \& Pekşen, Y. (2006). Pratisyen hekimlerde tükenmişlik, işe bağl1 gerginlik ve iş doyumu düzeyleri. Genel Tip Dergisi, 16(1), 9-14.

Şeşen, H. (2010). Adalet Algısının Tükenmişliğe Etkisi: İş Tatmininin Aracı Değişken Rolünün Yapısal Eşitlik Modeli İle Testi. Savunma Bilimleri Dergisi, 9(2), 67-90.

Şıklar, E. \& Tunalı, D. (2012). Çalışanların Tükenmişlik Düzeylerinin İncelenmesi: Eskişehir Örneği. Dumlupınar Üniversitesi Sosyal Bilimler Dergisi, (33), 75-84.

Tayfur, Ö., \& Arslan, M. (2012). Algılanan İş Yükünün Tükenmişlik Üzerine Etkisi: İş-Aile Çatışmasının Aracı Rolü. Hacettepe Üniversitesi İktisadi ve İdari Bilimler Fakültesi Dergisi, 30(1), 147-172.

Telli, E. (2012). Liderlik davranış tarzlarının çalışanların örgütsel tükenmişlik ve işten ayrılma eğilimleri üzerine etkisi: Konuyla ilgili bir uygulama, Trakya Üniversitesi Sosyal Bilimler Enstitüsü İşletme A.B.D. Yükseklisans tezi, Edirne.

Tett, R. P. \& Meyer, J. P. (1993). Job satisfaction, organizational commitment, turnover intention: Path analyses based on meta-analytic findings, Personnel Psychology, 46, 259-293.

Tsai, Y., Wu, S. W. \& Chen, S. C. (2017). Assessing the risk of turnover intention among hospital workers.
International Journal of Management, Economics and Social Sciences (IJMESS), 6(Special Issue), 244258.

Venkatraman, N. (1989). The concept of fit in strategy research: toward verbal and statistical correspondence. Academy of Management Review, 14, 423-444.

Voydanoff, P. (2004). Work role characteristics, family structure demands, and work/family conflict, Journal of Marriage and the Family, 50 (3), 749-761.

Wang, I. A., Lee, B. W. \& Wu, S. T. (2017). The relationships among work-family conflict, turnover intention and organizational citizenship behavior in the hospitality industry of Taiwan. International Journal of Manpower, 38(8), 1130-1142.

Wang, Y., Liu, L., Wang, J. \& Wang, L. (2012). Workfamily conflict and burnout among Chinese doctors: the mediating role of psychological capital. Journal of Occupational Health, 54(3), 232-240.

Wong, C. A. \& Laschinger, H. K. S. (2015). The influence of frontline manager job strain on burnout, commitment and turnover intention: A cross-sectional study, International Journal of Nursing Studies, 52(12), 1824-1833.

Yıldız, H. \& Örücü, E. (2016). Sağlık sektörü çalışanlarının pozitif psikolojik sermaye düzeylerinin belirlenmesine yönelik bir araştırma. Yönetim ve Ekonomi Araştırmaları Dergisi, 14(1), 269-285.

Yürür, S. \& Ünlü, A.G.O. (2011). Duygusal Emek, Duygusal Tükenme ve İşten Ayrılma Niyeti İlişkisi. ISGUC, The Journal of Industrial Relations and Human Resources, 13(2). 